\title{
Empowering communities for resolving the environmental crisis in forest and land fires in Riau Province
}

\author{
Yeni Rosilawati ${ }^{1, *}$, Asri Dewi ${ }^{1}$ \\ ${ }^{1}$ Universitas Muhammadiyah Yogyakarta, Indonesia
}

\begin{abstract}
The issue of the environment is becoming more complex. Regarding industry development, the impact of pollution, waste, infrastructure, and social pollution is getting worse. Especially in Riau Province, known for its disastrous peatland fires in recent years. This paper aims to identify the community development to address the environmental crisis in forest and land fires implemented in Kampung Jawa, Riau Province. This study utilized participatory observation and in-depth interviews with the local community. Secondary data were collected in the form of information on programs from the newspaper clippings and reports. The research discovered that local communities initiated the community development program to change the image of peatlands previously known as the source of haze disaster, which also has economic potential. The community development conducted by the local communities consisted of (i) Masyarakat Peduli Api (MPA) — a community volunteering to deal with disasters and suppress forest fires, (ii) pineapple farm and pineapple product processing, and (iii) peat Arboretum. This study also disclosed that community development carried out proactive dialogue and engagement with stakeholders, including farmers' communities, local communities, NGOs, and local government.
\end{abstract}

\section{Introduction}

The social issues today are becoming more and more complex. The effect of infrastructure, waste, and emissions on impaired road access due to mobility for company operations is even greater in connection with industry and business growth. The severe problems to resource issues increasingly being established in Indonesia are climate, economy, and infrastructure [1].

Forest fires are one of Indonesia's major disasters in the last few years. Especially on peatlands, fires last longer and are difficult to extinguish, as fires in the peat layer spread through the underground. Riau Province is one region that frequently experiences forest fires and has a wide peat area.

Land and forest fires in Riau Province have expanded to an area of 841.71 hectares (ha) throughout 2019, according to data from the Regional Disaster Management Agency

${ }^{*}$ Corresponding author: yenirosilawati@umy.ac.id 
(BPBD). The total burnt area, according to the Riau BPBD Data and Information Center, has surged by nearly 100 percent in the last three days. As of February 15, 2019, the total burnt area of land was around 497 ha [2].

Community development is a social activity seeking to improve the quality of life of people by empowering them to emphasize the principle of social participation [3]. It is carried out with a process of community development that starts with the theory of growth, namely the growth of principles, goals, and program priorities based on an appraisal of community needs. Community development combines the ideas of "community and development in which the concept of the community revolves around a group of people with a shared identity". Community development relies on the interactions between people and their joint actions rather than individual activities [3]. In most third world countries, rural communities find themselves permanently under siege by the destructive forces of 'modernizing development', based on the destruction of nature and collective wealth, and the concentration of individual interest - forces that an industrial, technocratic, materialistic society increasingly imposes in all corners of the world [4].

The next stage is the socialization of the program, aiming to make the target activities and the community aware and responsible for the ownership, implementation, and success of the programs. The socialization should be carried out through the media with proper communication information. Community development activities aim to increase the participation and accountability of empowerment programs [5].

Agents of change are concerned about rumors, problems, and community needs before carrying out community development activities. Community development activities, therefore, require the role of agents of change. The implementation of development programs also requires community participation, as they will experience the results in the final process [6]. Moreover, understanding concepts bridges the non-material aspects of development by viewing these activities as a process of acquiring new knowledge, information, and skills. In addition to being a tool, skills are also the result of the development process. As a research and practice field, community development has contributed to social welfare and more general human development through various avenues. These include, but are not limited to, leadership, mobilization, organization, and evaluation of intentional social change at the intersections of place and identity [7].

Community empowerment is a concept of economic development that embodies social values. The intended improvement is not just the economy but also prestige, dignity, selfconfidence, and self-esteem. The rationale for community empowerment is that efforts should be directed at the root of the problem to improve people's ability. This concept reflects a new paradigm for developers [8]. Community participation is integral to community development that facilitates the effective implementation of such initiatives and achieves objectives [9]. Moreover, community development also needs to involve the local values of the communities [10]. The Community Driven Development (CDD) approach can be used to develop contextualized strategies of enhancing community participation in development projects. [11]. Community participation in the implementation of the Community Development program is essential [12] Active participation is central to the sustenance of the groups as well as to the success of Community Development [13]. Community development can include local wisdom [14].

\section{Methodology}

This research employed a qualitative approach. Qualitative inquiry is a way of analysis by understanding the meaning of individuals or groups in social problems or human problems. The process comprises questions and procedures. This research is a case study. A case study refers to a detailed investigation of specific arrangements or events [15]. 
The research data were collected in two ways, firstly by in-depth interviews with the village head (R1), village officials (R2 and R3), and local communities (R4 and R5). Meanwhile, secondary data were obtained from the report of the community development program of Kampung Jawa and news about the Kampung Jawa empowerment program from online media. The collected data were analyzed using an interactive analysis model. This model consists of three analysis components called data reduction, data presentation, and concluding [16]. The location of this research was in Kampung Jawa, Riau Province, Indonesia.

\section{Findings and Discussion}

Community development was carried out through the following stages: (1) planning phase - the earliest process where the Kampung Jawa villagers and the local government determined and classified the problems faced by people with intellectual disabilities living in the village. (2) Action phase-the stage that deals with the appropriate methods and strategies of the community development program, carried out through mentoring. (3) Evaluation-measuring the success of the program implemented.

\subsection{Planning Phase}

Community development was initiated by the Kampung Jawa community led by the local leader. It aims to change the mentality of the peatlands communities, previously known as the source of the haze disaster, which also has economic potential in the form of pineapple agriculture, resulting in the well-being of the local community by empowering small and medium-sized enterprises if sustainably and adequately managed. The identification step involves the participation of the community, such as the local community, the local government, and NGOs. During the planning phase, the local community identifies their problems and engages in more discussions to solve them.

Participation becomes a critical part of achieving the goals set. The process began with problem identification. Society, along with the planners and the authorities, accessed group discussions through brainstorming and identifying opportunities, potentials, and constraints. The program focuses on community development with the Masyarakat Peduli Api (MPA) and the Tani Tunas Makmur group. The Tunas Makmur farmer group, consisting of 20 women and 22 men, plays an active role in producing processed pineapples such as bags made of pineapple leaf fiber, pineapple chips, and pineapple syrup. Kampung Gambut Berdikari program increases the capacity building of MPA through firefighting training and provision of facilities. Other programs arising are pineapple farm, peat Arboretum, and pineapple product processing.

\subsection{Implementation of the Program}

Community development involves different stakeholders, including the local community, local government, and also NGOs. The community development conducted by the local communities are as follows:

a. Masyarakat Peduli Api (MPA) is a community that has volunteered to deal with disasters and to suppress forest fires. Capacity building training of MPA aims to improve their ability to solve forest fires that mostly occur during Riau's dry season. The Community Empowerment Land and Forest Fire Mitigation is a superior environmental program. Masyarakat Peduli Api (MPA) has an important role and duty to control forest and land fires, as explained in the Regulation of the Director-General 
of Forest Protection and Nature Conservation No. P.2/IV-SET/2014. In carrying out this task, those caring about fire must work actively, voluntarily, and responsibly. The goal is that forest and land fires in the village area can be controlled and resolved. This program arose from environmental issues of land and forest fires in the rocky hills of recent times. In the middle of 2014-2015, land and forest fires hit 86 hectares of rock hills and resulted in moral and material losses such as burning people's gardens and houses, Acute Respiratory Infections (ARI) disease, and death due to the ARI.

The local government supports strengthening institutions, and increasing MPA capacity includes training, improving the quality of facilities and infrastructure, participatory mapping, provision of reservoir infrastructure, canals, and canal blocking. The community development project also helps the community with facilities such as fire fighting equipment and tools to obtain water. This program helps the community to move fast in disaster mitigation of forest fire.

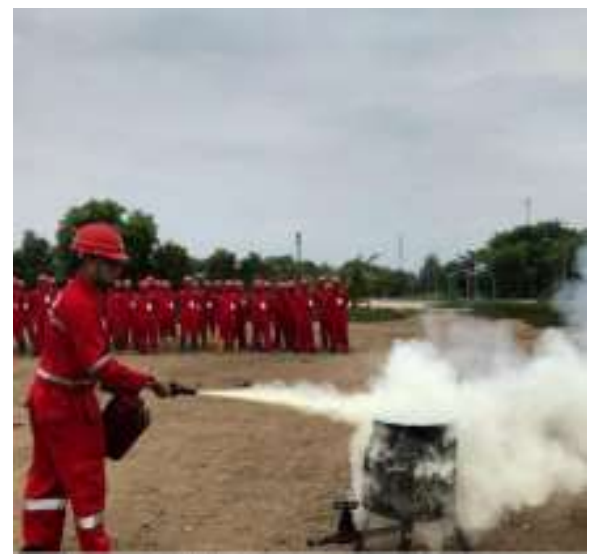

Fig.1. Volunteers to suppress forest fires

b. The Tani Tunas Makmur group runs the pineapple farm. The pineapple was chosen as the main crop in the peatland due to the nature of the plant, which does not absorb much water and has a high production value. At present, the group has been developed to become more integrated and institutionalized in cooperatives.

The pineapple farm increased from 0.5 to 14.5 ha that all planting requirements were in Sungai Pakning. From the upstream side, pineapple farming has provided pineapple seedlings independently with four types of seeds with various qualities, ranging from root buds, stem buds, stems, and crowns.

These four seedlings were used to plant 100,000 new lands planted in 10 ha of new land. Later, pineapple planting techniques have developed from monoculture to polyculture, initially by mixing plantations with hard plants such as matoa, jengkol, durian, and soursop up to 20,000 seedlings.

This planting technique is known as "Poligowo", combining the concepts of "Jajar Legowo" farming commonly used in annual crops for forest plants. This program helps farmers increase their income through pineapple farming and maintain soil conditions to be safe from the risk of land fires. 


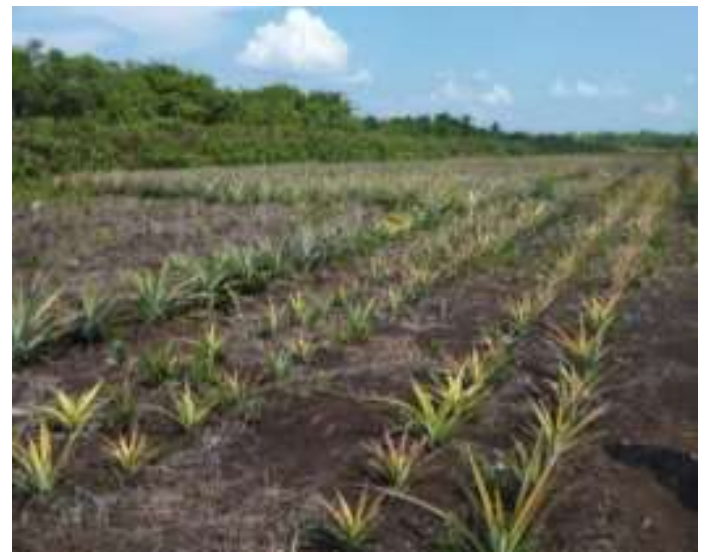

Fig. 2. The pineapple farm

c. The peat Arboretum began when the group managed the land donated by a member named Sadikin. The donated peatlands have become one of the natural laboratories for studying the diversity of flora and fauna in the peat forests. Various high quality and economically valuable timber and non-timber forest products and peat swamp forests can be produced, among others, Gonystylus bancanus, Dyera lowii, Gymnosperm macrophylla, Litsea sp, Shorea sp, Cratoxylum arborescens, Tetramerista glabra, Alstonia sp, Calophyllum sp, Combretocarpus rotundatus, Melanorrhoea wallichii. To use peat swamps, it is necessary to study soil, water, and vegetation. Vegetation diversity can be seen as an indicator of soil fertility, for example, in agriculture or forestry. For this reason, it is necessary to study the potential of peat swamps based on their vegetation. Peat Arboretum is expected to be one of the research laboratories for optimizing, ecologically, and economically using peat swamps.

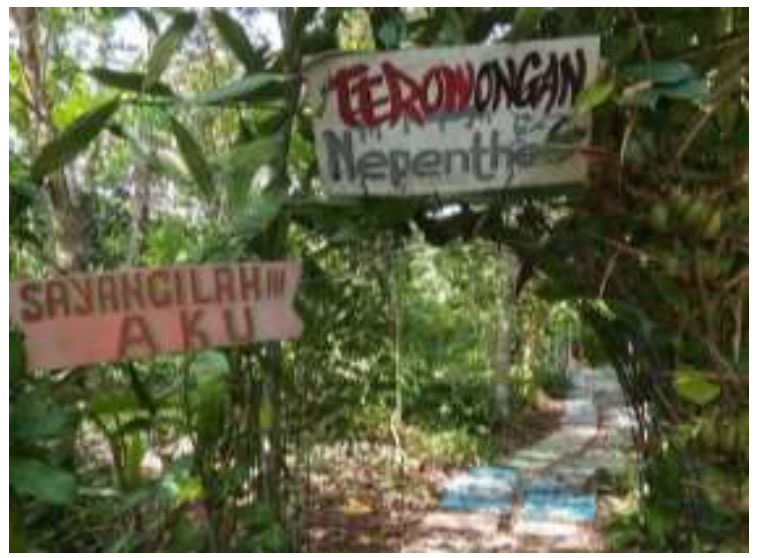

Fig.3. The Peat Arboretum

d. In addition to pineapple farming development, the program also processes pineapple products by the Tunas Makmur Farmer Group mothers. The program produces various processed products such as pineapple chips, sweet toffee (dodol), syrup, pineapple stick, and pineapple sweets. The group uses simple, appropriate technology for its processing, such as vacuum frying, spinner, press machine, and ph separator ( $\mathrm{Pi})$. This innovation not only ensures work safety but also speeds up production time to save labor costs. Full assistance and coaching are provided through this program, and this program has succeeded in increasing the income of group members through the sale of processed products. 
Local communities have played a role in effectively managing the program from planning up till the monitoring stage. The villagers were motivated to engage in their society and actively participate as members. The local communities gave and shared ideas to solve problems. The program requires community participation, as the community in the final process will experience the results.

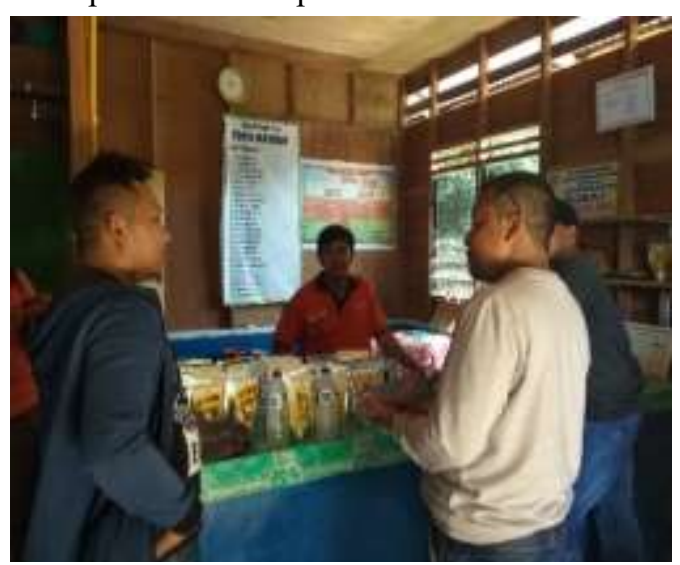

Fig.4.The Tunas Makmur Farmer Group

\subsection{Evaluation}

It measures the success of the program. People living around the peatlands can be socially and economically independent through an effective mentoring process as a community development strategy and support from both the government and the local community. The community development program implemented has succeeded in improving the social, economic, and living conditions of the members. The stigma of peatlands as an identical source of hazards has turned into an independent village. It is in line with the statement stating that community empowerment is a concept of economic development that encapsulates social values.

\section{Conclusions}

1. Community development focuses on the environmental and economic resolution. Community development in Kampung Jawa has a role in improving the welfare of the community and changing the image of the village as a source of hazards. The community development of the local communities consists of Masyarakat Peduli Api (MPA) - a community that has volunteered to deal with disasters and suppress forest fires, and the pineapple farm run by the Tani Tunas Makmur group. Peat Arboretum is one of the research laboratories for optimizing, ecologically, and economically using peat swamps.

2. Two ways of communicating in the form of discussions between local leaders and the community and other stakeholders have become one of the key successes of the community development program. From planning, designing the implementation of the program that gives priority to the role of the community in determining the program affects the level of success and benefits of the program.

3. This program has contributed to preserving peatlands into pineapple agriculture and natural laboratories as education for students. Utilization of peatlands into pineapple farming makes the land have a water content that can reduce forest fires. Community 
empowerment is also carried out for MPA with training and facilities, and Tunas Makmur farmers group produces various products and improves welfare.

Acknowledgments. The authors would like to thank Universitas Muhammadiyah Yogyakarta (UMY) for the grant financial assistance given in the fiscal year of 2020 .

\section{References}

1. B. Rudito and M. Famiola, Corporate Social Responsibility. Bandung: Rekayasa Sains, (2013)

2. D. Putsanra, Kebakaran Lahan dan Hutan di Riau Meluas, Capai 841 Ha pada 2019, accessed from https://tirto.id/kebakaran-lahan-dan-hutan-di-riau-meluas-capai-841-hapada-2019-dhhc (in bahasa Indonesia)

3. C.B Flora, C. B., J.L Flora, S.P. Gasteyer, Rural communities: Legacy + change (5th ed.). Boulder, CO: Westview Press, (2016)

4. V.M. Toledo, Indigenous Peoples and Biodiversity. Levin, S. et al. Encyclopedia of Biodiversity, (2013)

5. J.P Bispo and M.B Morais, Cad. Saúde Pública 2020; 36(8), pp. 1-9 (2020)

6. Zubaedi. Wacana Pembangunan Alternatif. Yogyakarta: Ar-Ruzza Media (2007)

7. J.J. Green. Res on Soc Work Prac, Vol 26(6):605-608, (2016) Z. Nasution, Komunikasi Pembangunan; Pengenalan Teori dan Penerapannya, Jakarta: PT Raja Grafindo Persada, (2004)

8. Z. Nasution, Komunikasi Pembangunan; Pengenalan Teori dan Penerapannya, Jakarta: PT Raja Grafindo Persada, (2004)

9. A. Budimanta, Pengelolaan Community Development. Jakarta: Indonesian Center for Sustainable Development, (2003)

10. K. Kongprasertamon, Manusya. Jour of Hum. Vol 10, 1, pp. 1-10, (2007)

11. F. Hassan, H. Ong'ayo, H. and M. Osore, Op. Jour of Soc. Sci. Vol 6, pp. 189-203.

12. K. Scott, A.S George, S.A Harvey, S. Mondal, G. Patel, et al, Beyond form and functioning: Understanding how contextual factors influence village health committees in northern India. PLoS ONE 12(8): e0182982, (2017)

13. K.F Omotesho, L. Ogunlade, M.A Lawal and F.B Kehind, Jour of Agri Fac of Gaz Univ, Vol 33, 21-27, (2016)

14. Y. Rosilawati, K. Mulawarman, N. Sofyan., E. Mulyantari, Intl Journ. Of Sust. Soc, Vol.12, No.2, pp.93 - 110, (2020).

15. J.W. Creswell, Research design, qualitative, quantitative and mixed methods approaches. Thousand Oaks, California USA: Sage Publications.

16. A. Bryman, Social Research Methods. Fourth Edition. New York, NY: Oxford University Press, (2012) 